\title{
Measuring the Casual Relationship Between the HRM Practices and Organizational Performance in Selected Commercial Banks in Bangladesh
}

\author{
Md.Tuhin Hussain ${ }^{1}$, Monzurul Islam Utsho ${ }^{2}$ \\ ${ }^{1,2}$ Lecturer, Department of Business Administration, Bangladesh University, Dhaka, Bangladesh
}

Email:monzurul.islam.utsho@gmail.com

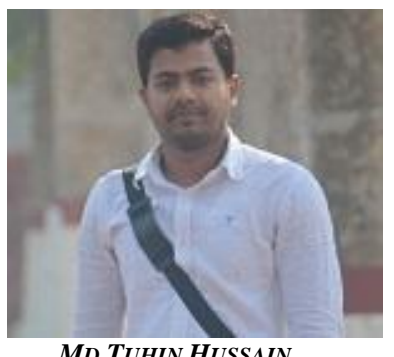

MD.TUHIN HUSSAIN

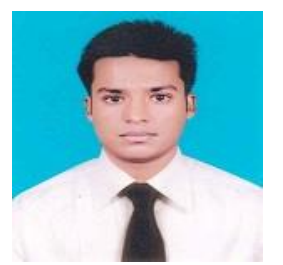

MONZURUL ISLAM UTSHO

\begin{tabular}{|c|c|}
\hline Keywords: & practices, \\
\hline $\begin{array}{l}\text { Organizational } \\
\text { Banking }\end{array}$ & $\begin{array}{l}\text { Performance, } \\
\text { organizations }\end{array}$ \\
\hline $\begin{array}{l}\text { Developing } \\
\text { Relationship. }\end{array}$ & Countries, \\
\hline
\end{tabular}

\begin{abstract}
A B S T R A C T
Impact of human resource management practices on organizational performance has been a widely research area for years. But unfortunately, very insufficient numbers of studies have been conducted on this area in the context of Bangladesh and other developing countries. This study was undertaken to fill this obvious research gap. The analysis of the data collected from ten banking organizations in Bangladesh shows that $H R$ practices have significant association with organizational performance. A survey has been conducted among 100 employees of different private and public banks within the Rajshahi city by using a structured questionnaire and analyzed them objectively. The result of this study indicates that the HRM practices of the organization have a significant impact on the performance of the organization. Finally the study concludes that the concerned authorities should be aware about the smooth operation of HR functions in order to improve the performance of the organization.
\end{abstract}

Citation: Md.Tuhin Hussain, Monzurul Islam Utsho (2018). Measuring the Casual Relationship Between the HRM Practices and Organizational Performance in Selected Commercial Banks in Bangladesh. International Journal of Advanced Multidisciplinary Scientific Research (IJAMSR ) ISSN:2581-4281 Vol 1, Issue 10, December, 2018, \#Art.1015, pp 34-42

\section{Introduction}

Human Resource practice is always a challenge for any organization to provide a set of service that is able to make the sense in terms of implementing the organization's strategic plan. In today's business world we cannot avoid the contribution of strategic practice, especially in the service sectors like fast growing banking sector. The banking service in the world is 


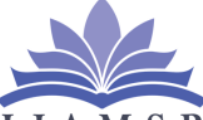

International Journal of

I J A M S R

\section{Advanced Multidisciplinary Scientific Research (IJAMSR) ISSN:2581-4281}

growing day by day. Bangladesh, although a developing country, is no omission from it. In the modern period of time Human Resource Management (HRM) practices became so recognizable and remarkable in every business sector of Bangladesh. The success of every organization is coming through the performance of the employees of that organization. The effectiveness of the employee performance is largely depends upon the Human Resource policy and practices. Therefore, the management should consider the extent of strategic HRM practices. The performance of any organization specially in a banking organization largely depends on the quality and

The competence of its employees and it is possible through proper practices of HR. The impact of Human Resource Management (HRM) practices popularly known as HR practices on organizational performance has been a leading area of research in the developed world for years.

\section{Objectives of the Study:}

The main objective of the study is to determine the impact of Human Resource Practices (Recruitment and selection Practices, reward, and Promotion Practice), on employee performance in banking sector of Bangladesh and specific objectives is as follows:

a) To measure the Casual Relationship between the HRM practices and Organizational Performance in the banking sectors of Bangladesh.

b) To analyze the impact of Training \& Development, Recruitment and Selection,

\author{
Reward \& Incentives on Organizational \\ performance in the banking sectors of \\ Bangladesh.
}

\section{Justification of the Study:}

The impact of human resource management (HRM) practices popularly known as HR practices on organizational performance has been a most important area of research in the developed world for many years. But unexpectedly, very limited number of researches have been conducted on the effect of HR practices on organizational performance in the perspective of developing countries in general and Bangladesh in particular. Therefore, in spite of valuable contribution supported by pragmatic evidence in this regard mostly from manufacturing companies in the United States and the other developed countries, the above mentioned pertinent research gaps in Bangladesh context after deep review of literature have led us to undertake this study. This study has also been conducted to fill the existing research gap and to explore the relationship between HR practices with organizational performance in the arena of banking sector in Bangladesh.

\section{Research Methodology:}

There are a number of HR practices that could be tested in line with organizational performance. Teseema \& Soeters (2006) have studied eight HR practices and their relationship with apparent organizational performance. These eight practices contain recruitment and selection practices, placement practices, training practices, compensation practices, employee performance evaluation practices, promotion practices, grievance procedure and pension or social security. Huselid (1995) 


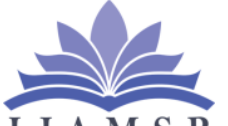

International Journal of Advanced Multidisciplinary Scientific Research (IJAMSR) ISSN:2581-4281

used eleven HRM practices in his study, which are personnel selection, performance appraisal, incentive compensation, job design, grievance procedures, information sharing, attitude assessment, labor management participation, recruitment efforts, employee training and promotion criteria. This study examines the connection between five HR practices, i.e. Training, Employee Empowerment, Performance Appraisal, Reward \& Incentives, Recruitment. Bangladesh is a developing country with very low per capita income and above five practices which have a relatively direct impact on financial earnings and social status of an organization may be considered the major determinants of the organization's performance. This is the reason these practices have been chosen for this study.

\section{Theoretical Framework and Hypothesis:}

This study identified organizational performance as dependent variable and HR functions are independent variables those are: training and development, reward and incentives, recruitment and selection, employee empowerment, performance appraisal. This study also aimed at constructing the regression model using multiple regression analysis. The model is as follows:

$\mathrm{Y}=\mathrm{a}+\mathrm{b}_{1} \mathrm{x}_{1}+\mathrm{b}_{2} \mathrm{x}_{2}+\mathrm{b}_{3} \mathrm{x}_{3}+--\cdot------+\mathrm{b}_{\mathrm{n}} \mathrm{x}_{\mathrm{n}}$.

Where,

$\mathrm{Y}=$ organizational performance

$\mathrm{x}_{1}, \mathrm{x}_{2}, \mathrm{x}_{3}$, and $\mathrm{x}_{\mathrm{n}}=$ The functions of HRM

$\mathrm{a}=$ constant

$b_{1}, b_{2}, b_{3}$, and $b_{n}=$ The coefficient
Relationship between the functions of HRM and organizational performance:

$\mathrm{H}_{0}=$ There is no significant impact of the functions of HRM on the organizational performance.

$\mathrm{H}_{\mathrm{a}}=$ There is a significant impact of the functions of HRM on the organizational performance.

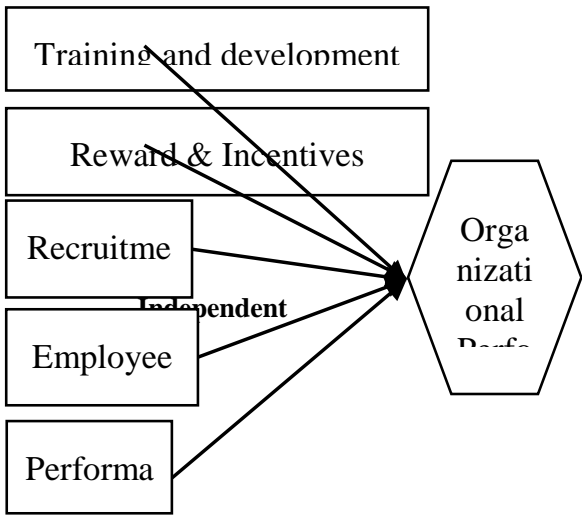

Figure 1: The theoretical

Variables:

$\mathrm{X} 1=$ Training and development

$\mathrm{X} 2=$ Reward \& Incentives

X3 $=$ Recruitment and selection

$\mathrm{X} 4=$ Employee empowerment $\mathrm{X} 5=$ Performance Appraisal

Dependent Variable: $Y=$ Organizational performance 


\section{International Journal of Advanced Multidisciplinary Scientific Research (IJAMSR) ISSN:2581-4281}

\section{Questionnaire Design:}

The questionnaire was based on a questionnaire used by Teseema et.al. (2006), Shahzad et al (2008), for measuring the impact of various HR practices on employee performance was taken into account while making questionnaire for this research. The reason for selecting this questionnaire is that it was used to study the impact of the same variables as in the present study and was well tested for reliability and validity scales. A questionnaire that was administered consisted of five HR practices which are Training (5 items), Recruitment (5 items), Reward \& Incentives (5 items), and Employee Empowerment (5 items), Performance Appraisal (5 items). The response was required on five points Lickert scales (starting from $5=$ strongly agree to $1=$ strongly disagree).

\subsection{Respondents:}

The participants included full time bank executives of different banks of Bangladesh. A total 100 questionnaires were distributed however 100 were received back. This was a sufficient sample size for analysis of results.

\subsection{Reliability and Validity Test:}

Before applying statistical tools, testing of the reliability of the scale is very much important as its shows the extent to which a scale produces consistent results if measurements were made repeatedly. This is done by determining the association in between scores obtained from different administrations of the scales. If the association is high, the scale yields consistent results, this is reliable.

\subsection{Types and Sources of data and the procedure of data:}

The proposed study will be used for collecting both quantitative and qualitative data from primary and secondary sources.

- Primary data: The study depends mainly on the primary data for which the researcher has visited the units or fields personally. These types of data have been collected through questionnaire survey method.

- Secondary data: Secondary data have been gathered mainly from the published article in the literature and the internet website of the relevant subject.

\subsection{Data Processing, Analysis and Presentation:}

Keeping the objectives of study in mind and considering the nature of collecting data, simple statistical analysis will be performed. Both descriptive and inferential statistic will be used to gather the answer of the research questions. The basic descriptive statistics such as: Frequency, percentages, means, trend analysis, etc. will be needed in the study. The inferential statistics will include correlation and regression analysis will be used to determine the relationship between related variables. 


\section{Literature Review:}

a) Azimet al. (2010) described research on the topic of Impact of Human Resources Practices on Job Satisfaction: Evidence from Manufacturing Firms in Bangladesh. This study aims at exploring the impact of HR practices on job satisfaction in the context of Bangladesh. A total of 60 responses from 20 manufacturing firms were collected and analyzed objectively. It was found that HR practices have significant associated with job satisfaction. In addition, Human Resource Planning (HRP), and Training and Development were found to have a positive impact on job satisfaction. It was also found that Training and Development has the greatest impact on job satisfaction. In this study, they analyzed data by entering wise method in a multiple regression analysis.

b) Mahmud and Idrish (2011) described research on the topic of The Impact of Human Resource Management Practices on Turnover of Bank Employees in Bangladesh. This study empirically evaluated six Human Resource (HR) practices (realistic job information, job analysis, work, family balance, career development, compensation and supervisor support) and their likely impact on the Employee Intention to leave in the Bangladeshi banks. The sample consisted of 233 employees working in different banks in Bangladesh. The data were gathered by administering questionnaires (Questions are designed with a five point Likert scale to measure HR practices and employee's intention to leave. Five points Likert type scale has been used in the questionnaire to measure HR practices). The results indicated job analysis, career development, compensation, realistic job information, variables were negative and significantly correlated with Employee Intention to Leave. Interestingly, work family balance was not negatively correlated with Employee Intention to Leave.

c) Majumder (2012) described research on the topic of Human Resource Management Practices and Employees' Satisfaction towards Private Banking Sector in Bangladesh. The focus of this study is to gain an insight into the current HRM practices and its impact on employee satisfaction on the private banking sector in Bangladesh. For conducting this research, 100 bank employees are selected from the chosen banks and out of this 88 employees responses properly, the response rate is 88 percent. The questionnaire consists of different questions on nine HRM dimensions such as recruitment and selection systems, compensation package, job security, career growth, training and development, management style, job design and responsibilities, reward and motivation and working environment. 


\section{International Journal of Advanced Multidisciplinary Scientific Research (IJAMSR) ISSN:2581-4281}

d) Mutasim \& Rahman (2013) described research on the topic of Relationship between Islamic Human Resource Management (IHRM) practices and trust: An empirical study. The purpose of this study is to explore and examines the theoretical frameworks of Islamic human resource management practices and trust in the organization. Additionally, to investigate the extent to which Islamic HRM practices inspire and revival employees' trust in the organization. This study comprised a sample of 236 Islamic Bank employees in Bangladesh. A crosssectional research design was used to examine the relationship between Islamic Human Resource Management practices and trust. Data was gathered based on personal administered questionnaire. This study results show that knowledge, understanding and practices of Islamic principles, recruitment and selection, training and development, and reward system significantly related to the trust.

e) Rahman et al. (2012) worked on the topic of the article was The Role of Human Resource Management practices on Job Satisfaction and Organizational Commitment in Banking Sector of Bangladesh- A Comparative Analysis. This study aims at exploring the impact of HRM practices on job satisfaction and organizational commitment at the banking sector in Bangladesh. Literature review revealed that the influencing factors relating to HRM practices on job satisfaction and organizational commitment are job security, reward, training and development, equity, attitude of the top management and work autonomy, etc. Data was collected through 1000 employees of different private and public banks within the five divisions (Dhaka, Rajshahi, Chittagong, Khulna and Sylhet) by using structured questionnaire based on five Likert scales and analyzed them objectively. For analysis purposes, they used various tests such as Chi- square test, ANOVA test and identified a number of key findings as to the effect of HRM practices on Job satisfaction and Organizational commitment in banking sector in Bangladesh.

f) Rana et al. (2014) worked on the topic of the article was Human Resource Management (HRM) Practices of the Banking Sector in Bangladesh: A Comparative study. This study investigates an analysis of human resources management practice and recommendations in the banking sector in Bangladesh. The research seeks to examine the human resources management practice in the banking sector. It evaluates and compares existing human resource management activities of employee recruitment and selection, job analysis methods, performance evaluation, audit, promotion scheme, training and development programs of five selective commercial banks. In this paper employees opinion on nine indicators is used to measure their levels of job satisfaction. 


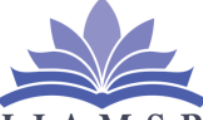

International Journal of Advanced Multidisciplinary Scientific Research (IJAMSR) ISSN:2581-4281

\section{Conceptual Framework:}

For more than a century now, human resource management, as a discipline and practice in the management of people in an organization, has evolved and developed into different areas. These disciplines and practices have gone through a process of trial and error, theory building and testing of various concepts by practicing managers and academics (Farnham \& Pimlott 1979; Storey 1989; Armstrong 1995). The underlying forces behind the evolution and development of human resource management have been (and still are) mainly environmental, and the quest for knowledge of better ways of acquiring and utilizing labor.The changing organizational environment in the marketplace, pushed managers to improve efficiency in the production and service delivery processes by increasing their ability to use the best practices of people management at the time. That is, employee management techniques or methods that would improve production, reduce service delivery costs, and at the same time ensure sustained availability of competent staff in the organization.

\section{Data Analysis:}

\subsection{Descriptive Statistical Analysis:}

This section revolves around analyzing the selected sample's demographic characteristics.

This table shows you that, there is no missing respondent in case of Educational qualification, Age of respondent, Gender, Marital status.
Table 1: Demographic information of the respondents.

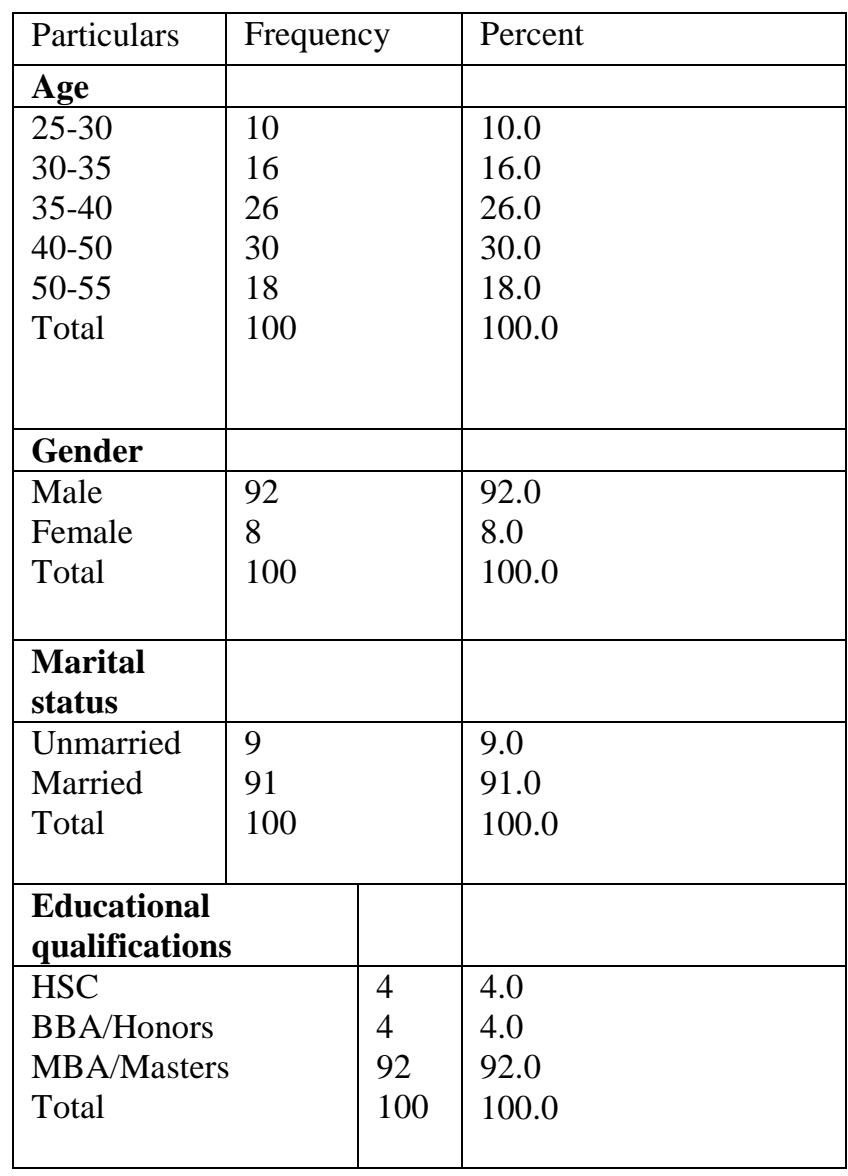

From the above table (table 1) we see that most of the respondents are in the age of 40 to $50(30 \%)$ years, some of them are in 35-40 (26\%) years and the rest of them are shown in the table; almost all of the respondent are male (92\%), and married (91\%) and $92 \%$ of respondents have the MBA/master degree.

\subsection{How the functions of HRM influence the organizational performance:}

This study used the multiple regression analysis to test the hypothesis. The output and the interpretation are as follows: 
Table 2: The regression model summary

\begin{tabular}{|r|r|r|r|r|}
\hline Model & \multicolumn{1}{|c|}{$\mathrm{R}$} & R Square & \multicolumn{1}{c|}{$\begin{array}{c}\text { Adjusted R } \\
\text { Square }\end{array}$} & $\begin{array}{l}\text { Std. Error of } \\
\text { the Estimate }\end{array}$ \\
\hline 1 & $.625^{\mathrm{a}}$ & .390 & .318 & .90681 \\
\hline
\end{tabular}

Predictors: (Constant), training and development, reward and incentives, recruitment and selection, employee empowerment, performance appraisal.

From the above table (table 2) it is found that the value of $\mathrm{R}$ is.625, it indicates that the relations between the dependent variable and the independent variables are strong enough to represent the model. It is also seen that the value of Adjusted $\mathrm{R}^{2}$ is.390, i.e. the dependent variable is $39 \%$ explained by the independent variable that are included in the model.

Table 3: ANOVA

\begin{tabular}{|c|c|c|c|c|c|c|}
\hline \multicolumn{2}{|c|}{ Model } & $\begin{array}{l}\text { Sum of } \\
\text { Squares }\end{array}$ & $\mathrm{df}$ & $\begin{array}{c}\text { Mean } \\
\text { Square }\end{array}$ & $\mathrm{F}$ & Sig. \\
\hline \multirow[t]{3}{*}{1} & Regression & 66.368 & 12 & 4.425 & 5.381 & $.000^{\mathrm{a}}$ \\
\hline & Residual & 103.611 & 88 & .822 & & \\
\hline & Total & 169.979 & 100 & & & \\
\hline
\end{tabular}

a) Predictors: (Constant), training and development, reward and incentives, recruitment and selection, employee empowerment, performance appraisal

b) Dependent Variable: organizational Performance
The above table (table 3 ) shows that the value of $\mathrm{F}$ is 5.381 at .05 level of significance, which is higher than the critical value of $\mathrm{F}$ from the F distribution (2.46) and it indicates that the study can reject the null hypothesis. That means there is a significant impact of the functions of HRM on the organizational performance.

Table 4: Coefficients ${ }^{\mathrm{a}}$

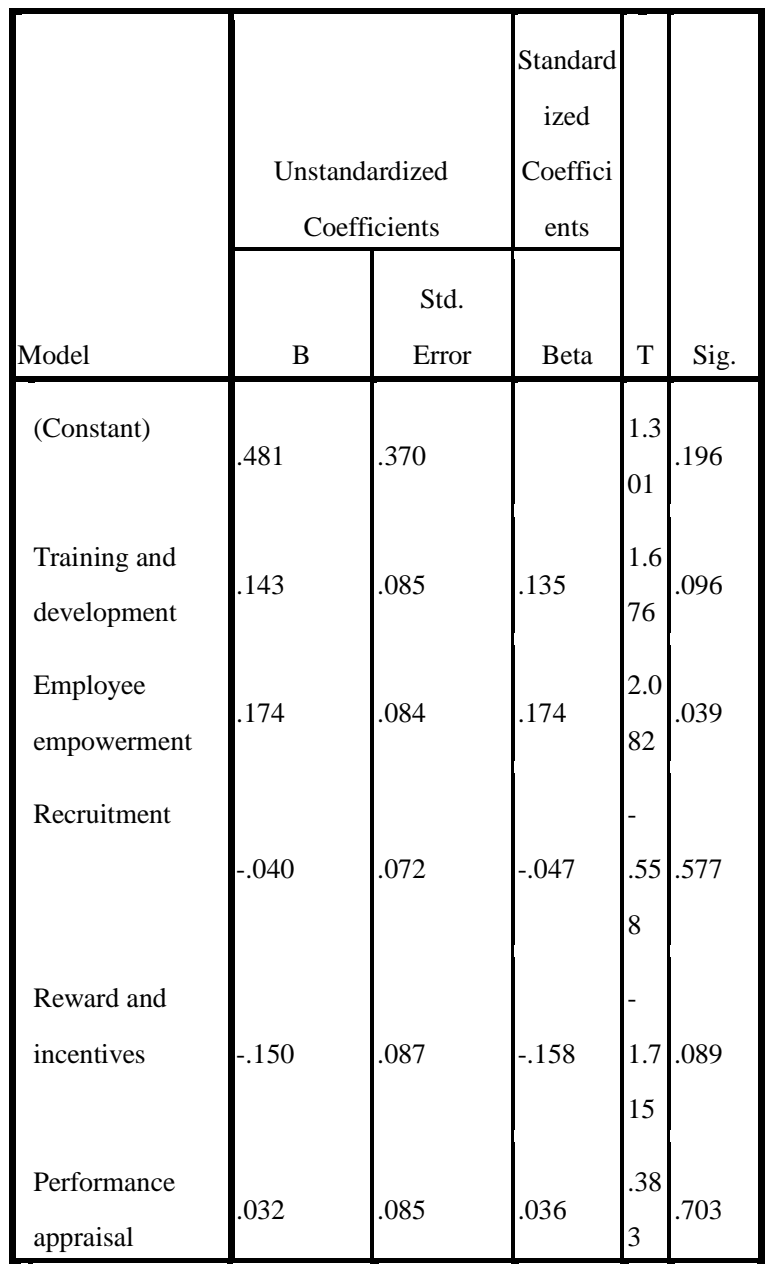




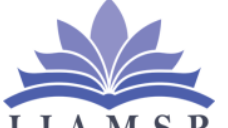

International Journal of Advanced Multidisciplinary Scientific Research (IJAMSR) ISSN:2581-4281

The above table (table 4) shows the value of the coefficients to construct the model. Since the beta value of standardized coefficients is 0 we will use the unstandardized coefficients. Hence the regression line will be:

Organizational performance $=.481+.143$ (Training and development) +.174 (employee empowerment)- .040 (recruitment)............ $+\ldots \ldots \ldots \ldots \ldots \ldots+.085$ (performance appraisal).

\section{Conclusion}

Although several studies have attempted to identify factors determining overall organizational performance with Bangladeshi Organizations, but, Satisfaction at banking sectors has remained a neglected aspect. The contribution of this study is the identification of factors that determine organizational performance, which is based on empirical research. It is concluded from the above discussion that the majority of the respondents are male, have a Masters degree, belongs to an age group of more than 35 . The success in the banking business largely depends on its training and development system, employee empowerment procedure, recruitment method, good training program, reward and incentive mechanism, and continuity of performance appraisal. In accordance with the finding of this study it is found that the performance of an organization depends on the smooth operation of the HRM practices. So the authorities and managers should be aware about the smooth operation of HRM practices in order to improve the performance of the organization.

\section{References}

1) Azim, M.T., Impact of Human Resources Practices on Job Satisfaction: Academy of Management Journal, vol. 37, no. 3, pp. 670-687, 2010.

2) Mahmud K. and Idrish S., The Impact of Human Resource Management Practices on Turnover of Bank Employees in Bangladesh; a Study on Private Commercial Banks in Bangladesh. Journal of Business and Technology, vol. IV, no. I, pp. 63-82, 2011.

3) Majumder T. H., Human Resource Management Practices and Employees' Satisfaction towards Private Banking Sector in Bangladesh:A comparative study between public \& private bank. Journal of Business Administration, vol. 33, no. 3\&4, pp. 23-42, 2012.

4) Mutasim N. \& Rahman A., Relationship between Islamic Human Resource Management (IHRM) practices and trust: An empirical study. Academy of Management Journal, vol. 12, no. 1, pp. 230-267, 2013.

5) Mizanur M.R., The Role of Human Resource Management practices on Job Satisfaction and Organizational Commitment in Banking Sector of Bangladesh- A Comparative Analysis: Southeast University Journal of Business Studies, vol. 1, pp. 153-166, 2012.

6) Rana M., Human Resource Management (HRM) Practices of the Banking Sector in Bangladesh: A Comparative Study Journal of Business and Technology, vol. IV, no. I, pp. 63-82, 2014.

7) Farnham, D. and Pimlott J., Understanding industrial relations. Burns \& Oates, 1995.

8) Storey, J., Introduction: from personnel management to human resource management, New perspectives on human resource management, vol. 1, p. 18, 1989.

9) Armstrong, P., Accountancy and HRM, Human resource management: a critical text. London: Routledge, pp. 142166, 1995.

10) Teclemichael Tessema, M. and Soeters, J.L., Challenges and prospects of HRM in developing countries: testing the HRM-performance link in the Eritrean civil service. The international journal of human resource management, vol.17, no. 1, pp. 86105, 2006.

11) [11] Shahzad, K., Bashir, S. and Ramay, M.I., Impact of HR practices on perceived performance of university teachers in Pakistan. International review of business research papers, vol. 4, no. 2, pp. 302315, 2008. 